Article

\title{
Antifungal Effect of Volatile Organic Compounds from Bacillus velezensis CT32 against Verticillium dahliae and Fusarium oxysporum
}

\author{
Xinxin Li ${ }^{1,2,3}$, Xiuhong Wang ${ }^{2,3}$, Xiangyuan Shi ${ }^{2,3}$, Baoping Wang ${ }^{1,2,3}$, Meiping Li ${ }^{1}$, Qi Wang ${ }^{1}$ \\ and Shengwan Zhang ${ }^{1, *}$ \\ 1 School of Life Science, Shanxi University, Taiyuan 030006, China; lixinxin_215@163.com (X.L.); \\ wangbp8409@163.com (B.W.); lmpmg@sxu.edu.cn (M.L.); wangqi@sxu.edu.cn (Q.W.) \\ 2 Shanxi Institute of Organic Dryland Farming, Shanxi Agricultural University, Taiyuan 030031, China; \\ wxhsxy75@163.com (X.W.); sxy75@yeah.net (X.S.) \\ 3 Research Center of Modern Agriculture, Shanxi Academy of Agricultural Sciences, Taiyuan 030031, China \\ * Correspondence: zswan@sxu.edu.cn
}

Received: 2 November 2020; Accepted: 15 December 2020; Published: 18 December 2020

\begin{abstract}
The present study focuses on the inhibitory effect of volatile metabolites released by Bacillus velezensis CT32 on Verticillium dahliae and Fusarium oxysporum, the causal agents of strawberry vascular wilt. The CT32 strain was isolated from maize straw compost tea and identified as B. velezensis based on 16S rRNA gene sequence analysis. Bioassays conducted in sealed plates revealed that the volatile organic compounds (VOCs) produced by the strain CT32 possessed broad-spectrum antifungal activity against eight phytopathogenic fungi. The volatile profile of strain CT32 was obtained by headspace solid-phase microextraction (HS-SPME) coupled with gas chromatography-mass spectrometry (GC-MS). A total of 30 volatile compounds were identified, six of which have not previously been detected in bacteria or fungi: (Z)-5-undecene, decyl formate, 2,4-dimethyl-6-tert-butylphenol, dodecanenitrile, 2-methylpentadecane and 2,2',5,5'-tetramethyl-1,1'-biphenyl. Pure compounds were tested in vitro for their inhibitory effect on the mycelial growth of $V$. dahliae and F. oxysporum. Decanal, benzothiazole, 3-undecanone, 2-undecanone, 2-undecanol, undecanal and 2,4-dimethyl-6-tert-butylphenol showed high antifungal activity, with benzothiazole and 2,4-dimethyl-6-tert-butylphenol being the most potent compounds. These results indicate that the VOCs produced by B. velezensis CT32 have the potential to be used as a biofumigant for management of vascular wilt pathogens.
\end{abstract}

Keywords: biocontrol; Bacillus velezensis; volatile organic compounds; vascular wilt pathogens

\section{Introduction}

Vascular wilt diseases, caused by Verticillium dahliae and Fusarium oxysporum, are devastating diseases of strawberry (Fragaria $\times$ ananassa Duch.) that severely affect the production of this crop. Due to the fact that the persistent resting structures produced by the pathogens are able to survive in the absence of hosts for long periods of time, vascular wilt diseases are particularly difficult to control [1,2]. Due to the lack of resistant strawberry cultivars, soil fumigation with methyl bromide is an effective way to manage vascular wilt diseases, but this fumigant has been withdrawn from routine use under the Montreal Protocol [3]. Non-chemical soil disinfections, such as steam sterilization and solarization, show potential in reducing soil inoculum levels, but these approaches may negatively impact soil microbial communities and associated functions [4]. Crop rotation is generally ineffective for Verticillium and Fusarium wilt of strawberry because of the wide host range of the pathogenic fungi. Therefore, the need to develop eco-friendly and highly efficient biocontrol agents (BCAs) for sustainable strawberry production is extremely urgent. 
Over the past few decades, impressive progress has been made in the development, registration and commercialization of BCAs based on microbial antagonists. Members of the Bacillus genus are good candidates as BCAs because they form endospores that can be readily formulated into biopesticide products [5,6]. Moreover, they produce a vast array of bioactive molecules with strong inhibitory potential against plant pathogens, such as bacteriocins, lipopeptides, siderophores, polyketides and volatile compounds $[7,8]$. Among these metabolites, non-volatile substances have received considerable research attention, whereas volatile compounds are less frequently studied. Volatile organic compounds (VOCs) are low-molecular-weight $(<300 \mathrm{Da}$ ) organic compounds that are characterized by a low boiling point, high vapor pressure and lipophilic character [9]. Several studies have demonstrated that the VOCs emitted by microbes may benefit plants by promoting growth, activating defence responses, and suppressing or eliminating potential pathogens [10-15]. Moreover, as naturally occurring chemicals, VOCs emitted by microorganisms are biodegradable. Therefore, microbial VOCs can be exploited as a sustainable strategy for use in crop enhancement and protection.

Muscodor albus, a biofumigant fungus, is the first commercially available BCA acting through its volatile emissions. In-package biofumigation with M. albus was shown to provide an effective control of fungal decay in grapes and extend their shelf life [16]. In addition, previous publications have shown the potential application of $M$. albus to protect building materials from biological damage and manage plant-parasitic nematodes of plants $[17,18]$. The successful application of M. albus inspired researchers to further explore the benefits of employing VOCs produced by antagonistic bacteria to control plant diseases.

Bacterial VOCs have been demonstrated to inhibit the growth and differentiation of numerous phytopathogenic fungi, suggesting that the complex mixtures of bacterial emissions represent a source of novel antifungal natural substances. For example, dimethyl disulfide (DMDS), a volatile sulphur compound frequently emitted by bacteria, has been shown to possess broad-range antifungal activities $[19,20]$. DMDS-containing products are used as novel soil fumigants. Recently, Zhang et al. [21] reported the inhibitory activity of 2,6-di-tert-butyl-4-methylphenol and 2,4-di-tert-butylphenol produced by B. siamensis G-3 against Botrytis cinerea and Rhizopus stolonifer both in vitro and in vivo. Given the diversity of microbes, only a small fraction of these volatile metabolites have been detected and studied, and more novel compounds with interesting bioactivities are yet to be discovered. A large number of phytopathogenic fungi have been used to investigate the antifungal potential of bacterial volatiles. However, the response of strawberry vascular wilt-causing agents to these volatile signals has largely been ignored in previous studies, despite the heavy losses they cause in strawberry production.

The objectives of this study were three-fold: (i) to investigate the response of two fungal vascular wilt pathogens to bacterial volatiles, (ii) to determine the chemical composition of bacterial VOCs, and (iii) to identify the bioactive compounds responsible for the antifungal effects. To achieve these aims, we isolated 73 strains of bacteria from maize straw compost tea and assessed their volatile-mediated effects on the mycelial growth of $V$. dahliae and F. oxysporum. From the above isolates, we selected B. velezensis CT32, which exhibited the highest antagonistic activity through the production of antifungal VOCs. Moreover, the VOCs produced by strain CT32 were qualitatively analysed by headspace solid-phase microextraction/gas chromatography-mass spectrometry (HS-SPME-GC-MS) and tested for their antifungal activity in vitro against $V$. dahliae and F. oxysporum.

\section{Materials and Methods}

\subsection{Phytopathogenic Fungi and Culture Conditions}

V. dahliae (ACCC 36196) and F. oxysporum f. sp. cucumerinum (ACCC 30220) were obtained from the Agricultural Culture Collection of China (ACCC), Beijing, China. Glomerella cingulata (CFCC 83279) and Thanatephorus cucumeris (CFCC 83233) were obtained from the China Forestry Culture Collection Center (CFCC). F. oxysporum f. sp. fragariae (FOF), F. oxysporum f. sp. niveum, Botryosphaeria dothidea and Botrytis cinerea were provided by the Research Center of Modern Agriculture, Shanxi Academy of 
Agricultural Sciences. The plant pathogens were grown on potato dextrose agar (PDA) plates in the dark at $28^{\circ} \mathrm{C}$, except B. cinerea, which was incubated at $25^{\circ} \mathrm{C}$.

\subsection{Isolation of Bacteria from Maize Straw Compost Tea}

Maize straw compost tea samples for the isolation of antagonistic bacteria were prepared as described previously [22]. Briefly, $10 \mathrm{~mL}$ of the compost tea was added to $90 \mathrm{~mL}$ of sterile distilled water in a $250 \mathrm{~mL}$ Erlenmeyer flask and shaken at $180 \mathrm{rpm}$ and $30{ }^{\circ} \mathrm{C}$ for $30 \mathrm{~min}$ on a rotary shaker. Serial 10-fold dilutions of the suspension were prepared in sterile distilled water, and aliquots $(200 \mu \mathrm{L})$ of each dilution were spread-plated onto nutrient agar (NA). After $48 \mathrm{~h}$ of incubation at $30{ }^{\circ} \mathrm{C}$, bacterial colonies with dissimilar morphologies were selected and further purified by streaking on NA plates. All isolates were routinely maintained on slants of NA at $4{ }^{\circ} \mathrm{C}$ until further use.

\subsection{Screening for Bacteria Producing Antifungal Volatiles}

Seventy-three bacterial isolates were tested for their volatile-mediated effect on the mycelial growth of $V$. dahliae and FOF using the sealed plate method. A Petri dish containing NA was inoculated by spreading $200 \mu \mathrm{L}$ of cell suspension $\left(1 \times 10^{7} \mathrm{cfu} \mathrm{m}^{-1}\right)$ of bacterial strain and incubated at $28^{\circ} \mathrm{C}$ for $24 \mathrm{~h}$. A $5 \mathrm{~mm}$ diameter mycelial plug was taken from an actively growing culture of the tested pathogen and placed in the centre of a second Petri dish containing PDA. The lids of the two plates were removed. Subsequently, the plate inoculated with the mycelial plug was inverted and placed over the bacterial plate. The two plates were sealed with 3 turns of Parafilm. Sealed plates with only mycelial plugs growing in them served as controls. All plates were incubated at $28^{\circ} \mathrm{C}$ until control plates were fully covered with mycelia of the tested pathogen. Three plates for each bacterial strain and control were used. The inhibition rate was calculated using the formula presented by Gao et al. [23]:

$$
\text { Inhibition rate }(\%)=\left(D_{\mathrm{CK}}-D_{\mathrm{TR}}\right) /\left(D_{\mathrm{CK}}-5 \mathrm{~mm}\right) \times 100
$$

where $D_{\mathrm{CK}}$ is the colony diameter of the target pathogen in the control and $D_{\mathrm{TR}}$ is the colony diameter of the target pathogen in the treatment.

The broad-spectrum antifungal effect of the VOCs produced by the selected antagonistic bacterium, designated as CT32, against 8 plant pathogenic fungi was determined using the same method described above.

\subsection{Analysis of Bacterial VOCs by HS-SPME-GC-MS}

\subsubsection{Sample Preparation}

Three millilitres of melted NA culture medium was added into $20 \mathrm{~mL}$ headspace vials. The vials containing NA were sterilized at $121^{\circ} \mathrm{C}$ for $20 \mathrm{~min}$. Then, $90 \mu \mathrm{L}$ of cell suspension of the strain CT32 $\left(1 \times 10^{7} \mathrm{cfu} \mathrm{m} \mathrm{m}^{-1}\right)$ was inoculated on the surface of the culture medium in sample vials. The vials were capped with polytetrafluoroethylene (PTFE)/silicone septa and incubated for $4 \mathrm{~d}$ at $28{ }^{\circ} \mathrm{C}$ in the dark. Three samples were prepared, and uninoculated vials containing only NA medium served as controls.

\subsubsection{HS-SPME Procedure}

An SPME fibre with 50/30 $\mu \mathrm{m}$ divinylbenzene/carboxen/polydimethylsiloxane (DVB/CAR/PDMS) coating (Supelco, Bellefonte, PA, USA) was conditioned following the manufacturer's instructions. The vials were positioned inside a water bath to equilibrate for $27 \mathrm{~min}$ at $74^{\circ} \mathrm{C}$, and then extraction was carried out by exposing the SPME fibre to the headspace of the vial for $53 \mathrm{~min}$. The trapped compounds were desorbed for 4 min within the GC injector at $250{ }^{\circ} \mathrm{C}$.

\subsubsection{GC-MS Analysis}

GC-MS analysis was performed on an Agilent 7890A GC coupled to a 5975C mass selective detector (MSD) (Agilent, Santa Clara, CA, USA). Chromatographic separation was carried out on 
an HP-5MS capillary column (30 $\mathrm{m} \times 0.25 \mathrm{~mm}$ ID, $0.25 \mu \mathrm{m}$ film thickness). Helium flow rate was $1 \mathrm{~mL} \mathrm{~min}{ }^{-1}$. Injector temperature was maintained at $250^{\circ} \mathrm{C}$, and the splitless mode was chosen for injection. The oven programme was: initial $40{ }^{\circ} \mathrm{C}$ with a $2 \mathrm{~min}$ hold, ramped to $110^{\circ} \mathrm{C}$ at $4{ }^{\circ} \mathrm{C} \mathrm{min}-1$, ramped to $130{ }^{\circ} \mathrm{C}$ at $2{ }^{\circ} \mathrm{C} \mathrm{min}^{-1}$ (held for $2 \mathrm{~min}$ ), ramped to $150^{\circ} \mathrm{C}$ at $2{ }^{\circ} \mathrm{C} \mathrm{min}{ }^{-1}$ (held for $2 \mathrm{~min}$ ), ramped to $200{ }^{\circ} \mathrm{C}$ at $3{ }^{\circ} \mathrm{C} \mathrm{min}-1$, ramped to $300{ }^{\circ} \mathrm{C}$ at $30{ }^{\circ} \mathrm{C} \min ^{-1}$ (held for $5 \mathrm{~min}$ ). The total run time was $68.5 \mathrm{~min}$. MSD settings: electron impact mode at $70 \mathrm{eV}$, full scan acquisition mode, scan range $33-500 \mathrm{~m} / \mathrm{z}$. Ion source temperature was $230{ }^{\circ} \mathrm{C}$. Quadrupole temperature was $150{ }^{\circ} \mathrm{C}$. The retention index (RI) of each volatile compound was calculated using $n$-alkanes $\left(C_{7}-C_{40}\right)$ as reference compounds, as described by Bianchi et al. [24]. Identification of bacterial VOCs was accomplished by comparing the obtained mass spectra with those stored in the National Institute of Standards and Technology (NIST) Mass Spectral Library (version 11) as well as by comparing the determined RIs with those reported in the literature. The relative amounts (RA) of the detected volatile compounds were calculated by dividing the area data of each component by the summed total peak area of all components. The analysis of NA medium was performed under the same conditions.

\subsection{Effect of Synthetic VOCs on Mycelial Growth of V. dahliae and FOF}

Pure standards of 26 commercially available VOCs produced by strain CT32 and identified by GC-MS analysis were purchased from Sigma-Aldrich LLC (Saint Louis, USA), Aladdin Reagent Inc. (Shanghai, China), and Tokyo Chemical Industry Co., Ltd. (Tokyo, Japan). These VOC standards were tested to determine their effect against the mycelial growth of $V$. dahliae and FOF. A sterile filter paper disc containing $100 \mu \mathrm{L}$ of each pure compound was placed inside a Petri dish. For solid standards, $100 \mathrm{mg}$ of each solid alcohol was dissolved with $100 \mu \mathrm{L}$ methanol, $100 \mathrm{mg}$ of each solid ketone was dissolved with $100 \mu \mathrm{L}$ acetone. The remaining solid standards were added directly to the filter paper. The lid of the Petri dish was replaced by the PDA plate previously inoculated with a $5 \mathrm{~mm}$ diameter mycelial plug of the target pathogen in the centre. The two plates were quickly sealed with Parafilm and incubated at $28{ }^{\circ} \mathrm{C}$ in the dark. The inhibition rate was calculated according to the formula previously described in Section 2.3. In the control plates, pure VOCs were substituted by an equivalent amount of sterile distilled water. The experiment was performed in triplicate.

\subsection{Identification of Strain CT32}

Strain CT32 was subjected to Gram staining. The spore formation and cell morphology of strain CT32 were observed under a transmission electron microscope as well as a light microscope. Then, 16S rRNA gene sequencing was conducted to assess the phylogenetic relationship of the unidentified bacterium to other related taxa. Genomic DNA was extracted using an Ezup Column Bacteria Genomic DNA Purification Kit (Sangon Biotech, Shanghai, China). Amplification was performed using the primer pair 27F (5'-AGTTTGATCMTGGCTCAG-3') and 1492R (5'-GGTTACCTTGTTACGACTT-3') under the conditions described by Zhang et al. [21]. The purified PCR product was sequenced by Sangon Biotech Co., Ltd. The 16S rRNA gene sequences of unknown bacterium and of closely related type strains were aligned using Clustal X (version 2.0). The phylogenetic tree was built using MEGA (version 6.0) via the neighbor-joining method.

\subsection{Statistical Analysis}

Statistical analyses of inhibition rates were performed using SPSS 21.0 software. Data were calculated and subjected to one-way ANOVA.

\section{Results}

\subsection{Screening for Bacteria with Volatile-Mediated Antagonistic Activity}

In total, 73 isolates of bacteria with distinct morphologies were isolated from maize straw compost tea. Among these isolates, five bacterial strains produced volatiles able to significantly $(p<0.05)$ inhibit 
the mycelial growth of both $V$. dahliae and FOF (Table 1). One of these bacterial strains, designated as CT32, was found to have the highest antagonistic activity. Upon exposure to VOCs emitted by strain CT32, the mycelial growth of V. dahliae and FOF was reduced by $66.94 \%$ and $45.72 \%$, respectively. Therefore, strain CT32 was selected for further investigation.

Table 1. Inhibitory effect of volatile compounds produced by antagonistic bacteria on the mycelial growth of $V$. dahliae and F. oxysporum f. sp. fragariae (FOF).

\begin{tabular}{ccccccc}
\hline \multirow{2}{*}{ Bacterial Isolate } & \multicolumn{2}{c}{ Colony Diameter of Control $(\mathbf{m m})$} & \multicolumn{2}{c}{ Colony Diameter of Treatment $(\mathbf{m m})$} & \multicolumn{2}{c}{ Inhibition Rate $(\%)$} \\
\cline { 2 - 7 } & V. dahliae & FOF & V. dahliae & FOF & V. dahliae & FOF \\
\hline CT11 & $81.22 \pm 0.70$ & $87.47 \pm 0.64$ & $56.12 \pm 0.89$ & $54.18 \pm 2.58$ & $32.93 \pm 1.17 \mathrm{~d}^{1}$ & $40.36 \pm 3.13 \mathrm{~b}$ \\
CT32 & $81.22 \pm 0.70$ & $87.47 \pm 0.64$ & $30.20 \pm 1.57$ & $49.77 \pm 1.53$ & $66.94 \pm 2.06 \mathrm{a}$ & $45.72 \pm 1.86 \mathrm{a}$ \\
CT56 & $81.22 \pm 0.70$ & $87.47 \pm 0.64$ & $47.85 \pm 0.60$ & $68.55 \pm 1.70$ & $43.78 \pm 0.79 \mathrm{~b}$ & $22.94 \pm 2.06 \mathrm{~d}$ \\
CT58 & $81.22 \pm 0.70$ & $87.47 \pm 0.64$ & $52.55 \pm 2.19$ & $65.37 \pm 1.03$ & $37.61 \pm 2.87 \mathrm{c}$ & $26.80 \pm 1.25 \mathrm{c}$ \\
CT64 & $81.22 \pm 0.70$ & $87.47 \pm 0.64$ & $67.82 \pm 1.26$ & $79.38 \pm 0.83$ & $17.58 \pm 1.65 \mathrm{e}$ & $9.80 \pm 1.01 \mathrm{e}$ \\
\hline
\end{tabular}

${ }^{1}$ Data are the mean \pm standard deviation. In the same column, data with different lowercase letters are significantly different according to Duncan's multiple range test $(p<0.05)$.

\subsection{In Vitro Antifungal Activity of VOCs Produced by Strain CT32}

The VOCs emitted by strain CT32 significantly $(p<0.05)$ inhibited the mycelial growth of all tested pathogens, although with different inhibition extents (Figure 1). V. dahliae was the most susceptible fungus to VOCs emitted by strain CT32, and its mycelial growth was inhibited by $66.67 \%$. In contrast, T. cucumeris showed the greatest resistance to bacterial volatiles. Additionally, the VOCs produced by strain CT32 significantly reduced the mycelial growth of G. cingulata, B. cinerea, B. dothidea, F. oxysporum f. sp. niveum, FOF and F. oxysporum f. sp. cucumerinum, with percentages of inhibition ranging from $19.76 \%$ to $55.02 \%$. The suppressive effect of the VOCs emitted by strain CT32 on the in vitro growth of eight pathogenic fungi is presented in Figure 2.

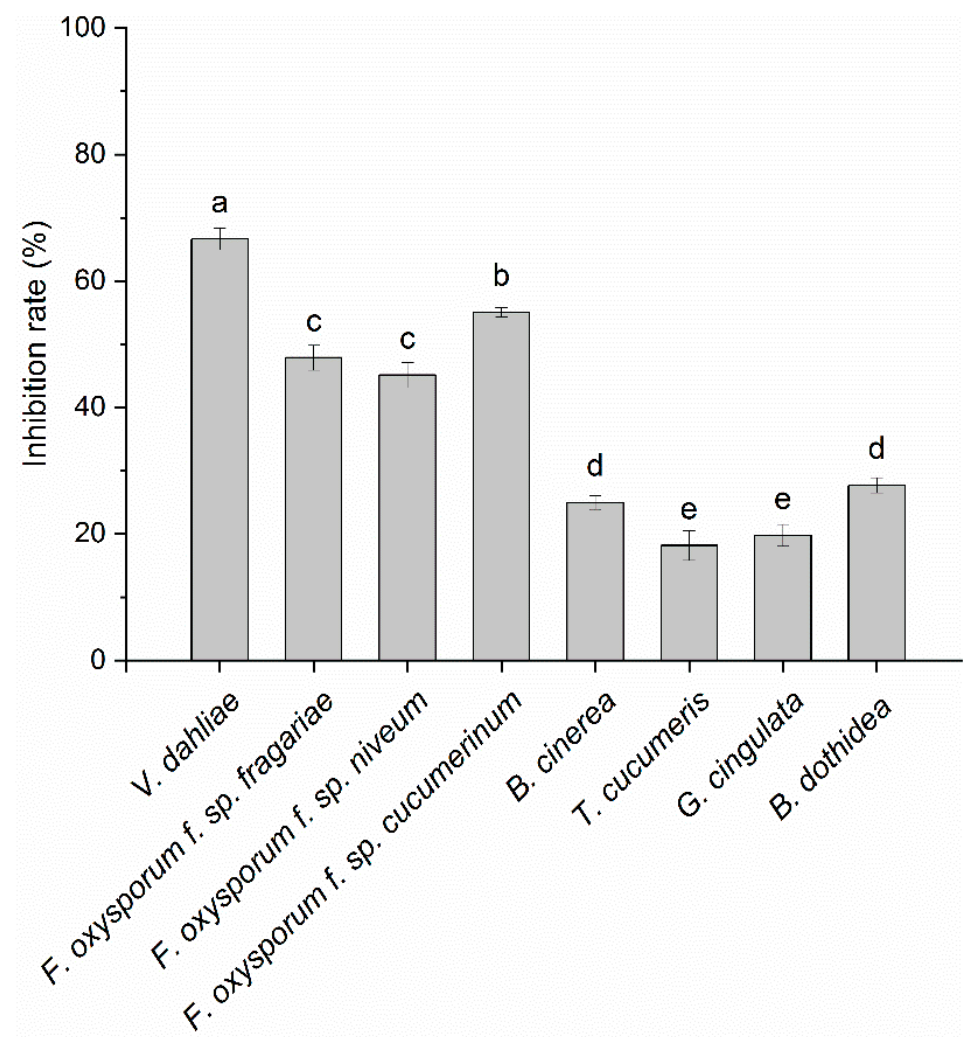

Figure 1. Inhibitory effect of volatile organic compounds (VOCs) produced by strain CT32 on the mycelial growth of 8 plant pathogenic fungi. Values with different lowercase letters are significantly different according to Duncan's multiple range test at the 0.05 level. 


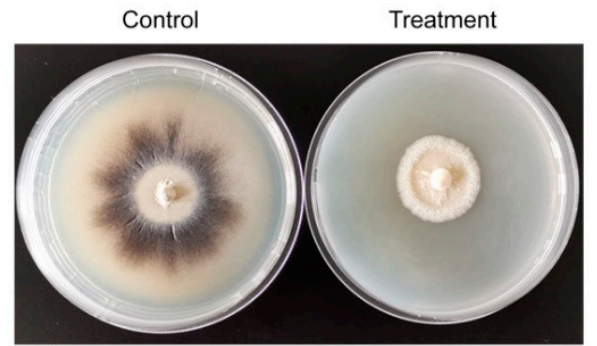

(a)

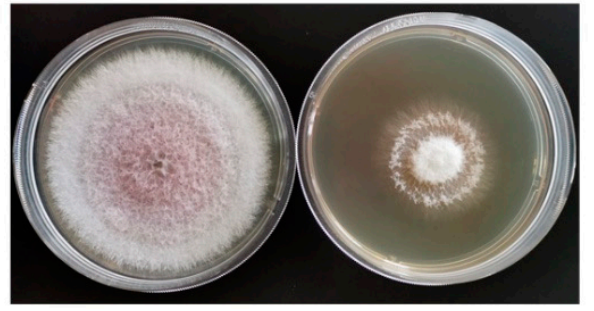

(c)

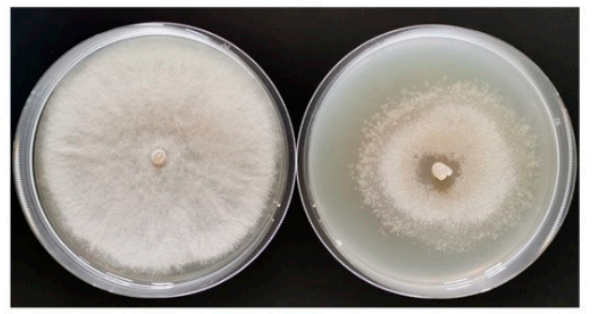

(e)

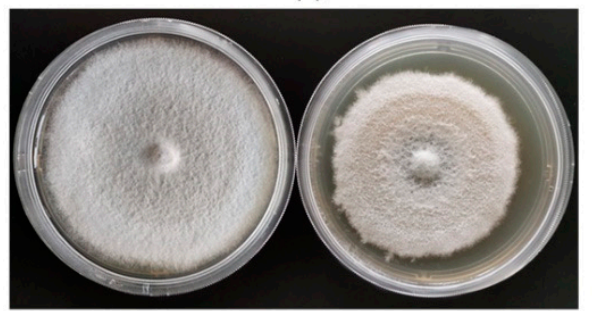

(g)

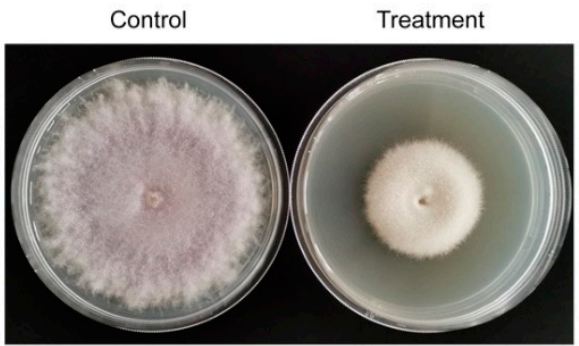

(b)

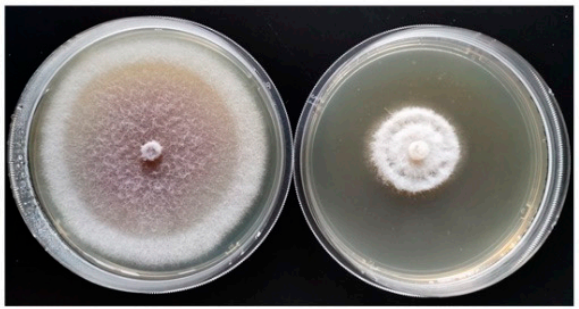

(d)

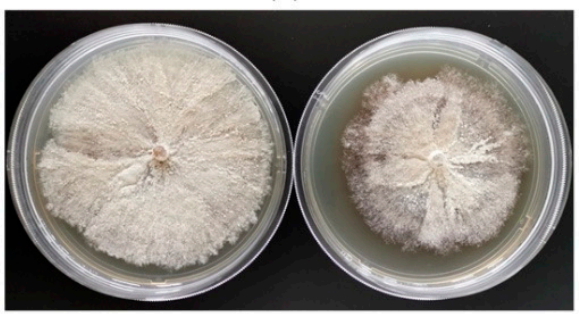

(f)

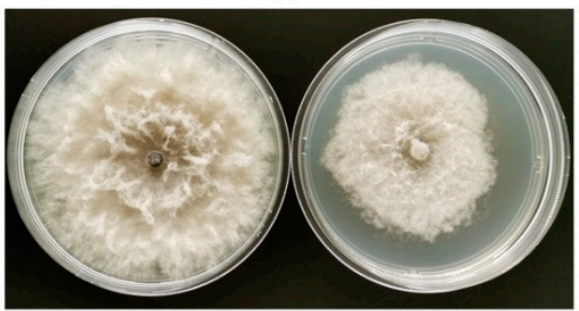

(h)

Figure 2. Effect of VOCs emitted by strain CT32 on the growth of 8 phytopathogenic fungi in vitro. In the sealed plates test, fungi in the control groups were cultured on potato dextrose agar (PDA) medium. The mycelial growth of fungi in the treatment groups was suppressed upon exposure to volatiles emitted by strain CT32. (a) V. dahliae; (b) F. oxysporum f. sp. fragariae; (c) F. oxysporum f. sp. niveum; (d) F. oxysporum f. sp. cucumerinum; (e) B. cinerea; (f) T. cucumeris; (g) G. cingulata; (h) B. dothidea.

\subsection{HS-SPME-GC-MS Analysis of VOCs Produced by Strain CT32}

The total ion chromatogram of VOCs emitted by strain CT32 is shown in Figure 3. A total of 30 volatile compounds derived from strain CT32, i.e., eight alkanes, six ketones, five alcohols, four aldehydes, two phenols, one alkene, one thiazole, one ester, one nitrogen compound and one biphenyl, were identified by GC-MS (Table S1). Alkanes, ketones, alcohols, and aldehydes were found to be the predominant VOCs emitted by strain CT32, which constituted $76.67 \%$ of the 30 detected compounds. The relative amounts of aldehydes, alcohols, ketones, and alkanes were calculated to account for $50.32 \%, 24.31 \%, 11.28 \%$ and $2.75 \%$ of the total volatile components, respectively. The most abundant volatile compound was dodecanal (48.56\%), followed by 1-dodecanol (10.27\%), 2-undecanol $(8.46 \%)$, 2-undecanone (3.37\%) and 2-dodecanol (3.24\%). 


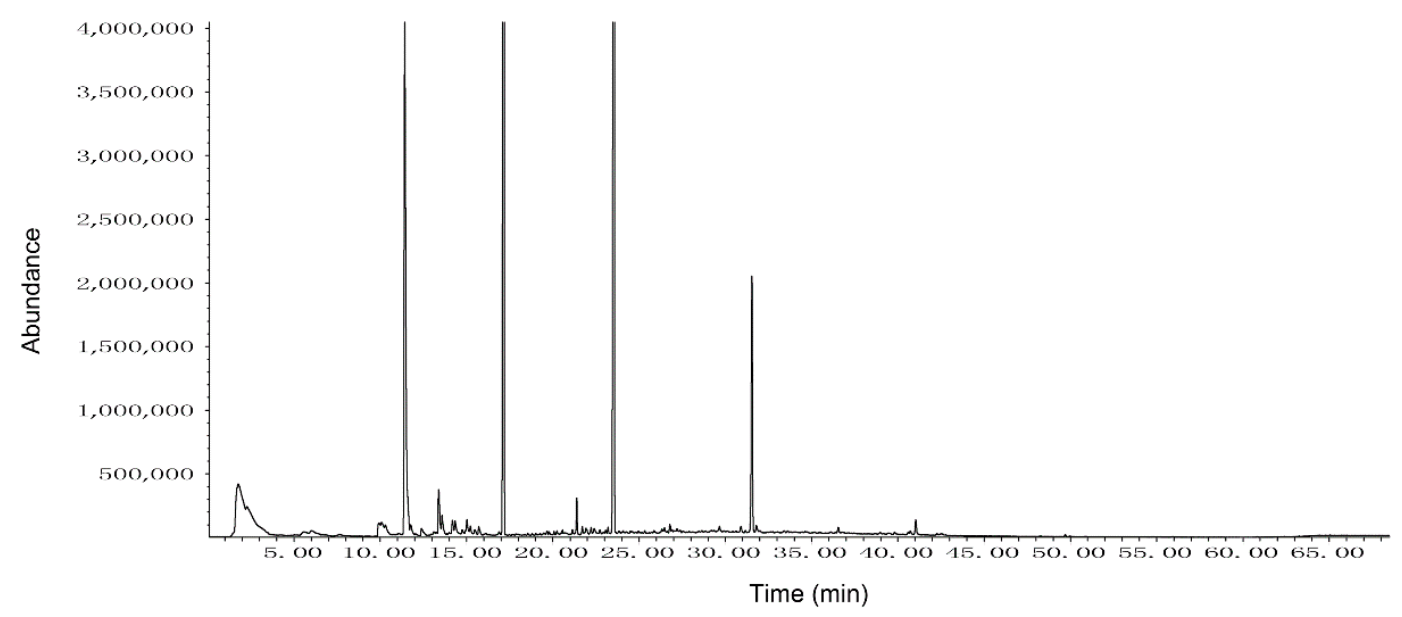

(a)

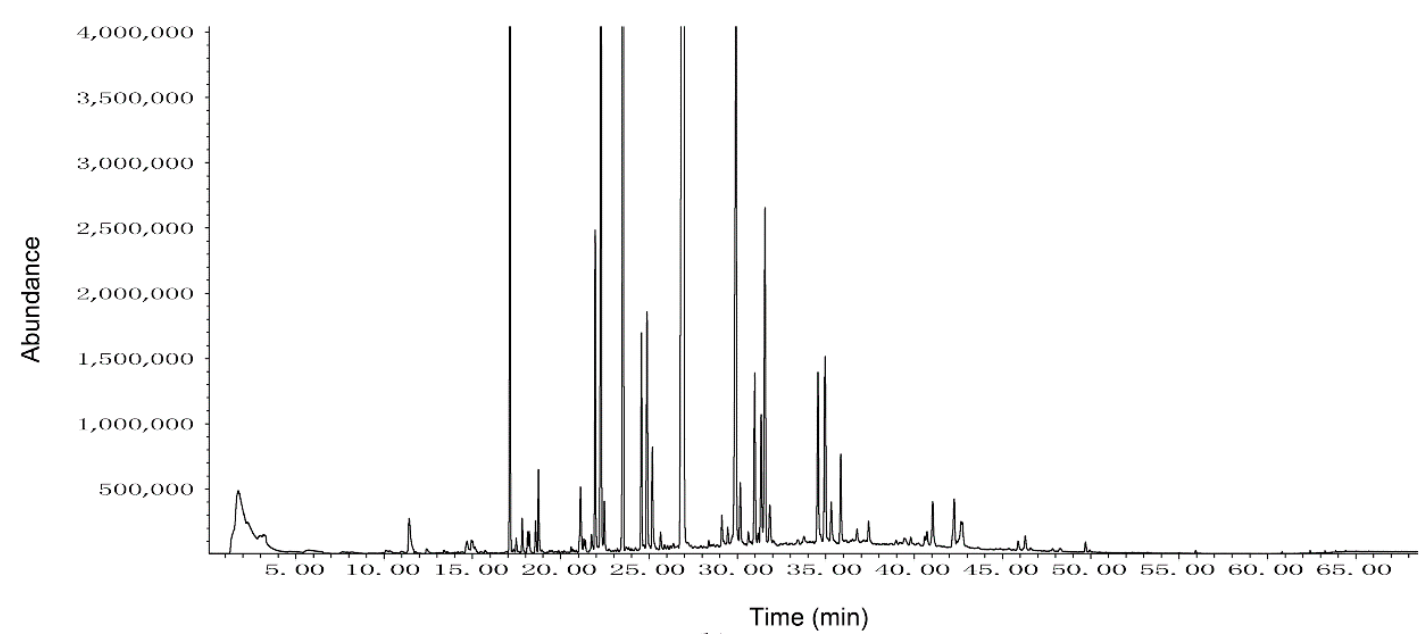

(b)

Figure 3. (a) Total ion chromatogram of VOCs from uninoculated nutrient agar (NA) medium; (b) total ion chromatogram of VOCs from strain CT32.

\subsection{Antifungal Activity of Synthetic VOCs against V. dahliae and FOF}

As shown in Table 2, 26 out of the 30 volatile compounds were commercially available and tested for their antifungal activities against $V$. dahliae and FOF in vitro. Benzothiazole significantly $(p<0.05)$ inhibited the mycelial growth of the two target pathogens. Furthermore, 2,4-dimethyl-6-tert-butylphenol proved highly suppressive against both fungi, showing an inhibition rate greater than $90 \%$. The inhibition rates of dodecanenitrile were $51.10 \%$ against $V$. dahliae and $20.04 \%$ against FOF. All four aldehydes negatively impacted both pathogens, but the strength of their impact varied. Although dodecanal was the most abundant compound in the headspace of strain CT32, it exhibited significant but weak inhibitory activity. Decanal and undecanal possessed high antifungal activity against $V$. dahliae and FOF, but they were produced in low amounts. In general, FOF was more tolerant to alcohols than $V$. dahliae. The antifungal activity of alcohols was negatively correlated with the number of carbon atoms in the alcohols, and thus, 2-undecanol showed the highest inhibitory activity. Among the six ketones tested for bioactivity against $V$. dahliae and FOF, 2-undecanone showed the highest level of inhibition under the experimental conditions, followed by 3-undecanone and 2-dodecanone. 
Table 2. Inhibitory effect of 26 synthetic VOCs on the mycelial growth of $V$. dahliae and FOF.

\begin{tabular}{|c|c|c|c|c|c|c|}
\hline \multirow{2}{*}{ Compound } & \multicolumn{2}{|c|}{ Colony Diameter of Control (mm) } & \multicolumn{2}{|c|}{ Colony Diameter of Treatment (mm) } & \multicolumn{2}{|c|}{ Inhibition Rate (\%) } \\
\hline & V. dahliae & FOF & V. dahliae & FOF & V. dahliae & FOF \\
\hline Undecane & $83.05 \pm 0.83$ & $87.75 \pm 0.25$ & $88.00 \pm 0.00$ & $88.00 \pm 0.00$ & $-\mathrm{p}^{1}$ & $-\mathrm{O}$ \\
\hline Decanal & $83.05 \pm 0.83$ & $87.75 \pm 0.25$ & $21.13 \pm 1.21$ & $35.03 \pm 0.96$ & $79.33 \pm 1.54 \mathrm{~d}^{2}$ & $63.71 \pm 1.16 c$ \\
\hline Benzothiazole & $83.05 \pm 0.83$ & $87.75 \pm 0.25$ & $5.00 \pm 0.00$ & $5.00 \pm 0.00$ & $100.00 \pm 0.00 \mathrm{a}$ & $100.00 \pm 0.00 \mathrm{a}$ \\
\hline 3-Undecanone & $83.05 \pm 0.83$ & $87.75 \pm 0.25$ & $32.75 \pm 1.75$ & $42.85 \pm 0.41$ & $64.45 \pm 2.24 \mathrm{f}$ & $54.26 \pm 0.49 \mathrm{e}$ \\
\hline 2-Undecanone & $83.05 \pm 0.83$ & $87.75 \pm 0.25$ & $25.47 \pm 2.87$ & $40.62 \pm 1.62$ & $73.78 \pm 3.67 \mathrm{e}$ & $56.96 \pm 1.95 \mathrm{~d}$ \\
\hline 2-Undecanol & $83.05 \pm 0.83$ & $87.75 \pm 0.25$ & $24.42 \pm 1.23$ & $41.83 \pm 1.15$ & $75.12 \pm 1.58 \mathrm{e}$ & $55.49 \pm 1.40 \mathrm{de}$ \\
\hline Undecanal & $83.05 \pm 0.83$ & $87.75 \pm 0.25$ & $12.05 \pm 0.91$ & $49.25 \pm 1.09$ & $90.97 \pm 1.17 c$ & $46.53 \pm 1.32 \mathrm{f}$ \\
\hline 2-Dodecanone & $83.05 \pm 0.83$ & $87.75 \pm 0.25$ & $54.47 \pm 1.50$ & $55.35 \pm 2.93$ & $36.62 \pm 1.92 \mathrm{~h}$ & $39.15 \pm 3.54 \mathrm{~g}$ \\
\hline 2-Dodecanol & $83.05 \pm 0.83$ & $87.75 \pm 0.25$ & $43.75 \pm 2.41$ & $64.22 \pm 1.55$ & $50.35 \pm 3.09 \mathrm{~g}$ & $28.44 \pm 1.87 \mathrm{~h}$ \\
\hline 2,4-Dimethyl-6-tert-butylphenol & $83.05 \pm 0.83$ & $87.75 \pm 0.25$ & $8.45 \pm 0.43$ & $12.33 \pm 0.38$ & $95.58 \pm 0.55 \mathrm{~b}$ & $91.14 \pm 0.46 b$ \\
\hline Tetradecane & $83.05 \pm 0.83$ & $87.75 \pm 0.25$ & $86.75 \pm 0.87$ & $88.00 \pm 0.00$ & - nop & $-\mathrm{O}$ \\
\hline Dodecanal & $83.05 \pm 0.83$ & $87.75 \pm 0.25$ & $61.75 \pm 1.24$ & $80.58 \pm 1.28$ & $27.29 \pm 1.59 \mathrm{i}$ & $8.66 \pm 1.55 j$ \\
\hline 1-Dodecanol ${ }^{4}$ & $83.05 \pm 0.83$ & $87.75 \pm 0.25$ & $59.55 \pm 1.50$ & $71.25 \pm 1.91$ & $30.11 \pm 1.93 \mathrm{i}$ & $19.94 \pm 2.31 \mathrm{i}$ \\
\hline Dodecanenitrile & $83.05 \pm 0.83$ & $87.75 \pm 0.25$ & $43.17 \pm 2.36$ & $71.17 \pm 1.61$ & $51.10 \pm 3.03 \mathrm{~g}$ & $20.04 \pm 1.94 \mathrm{i}$ \\
\hline 2-Tridecanone ${ }^{3}$ & $83.05 \pm 0.83$ & $87.75 \pm 0.25$ & $82.52 \pm 0.23$ & $84.13 \pm 1.04$ & $0.68 \pm 0.29 \mathrm{~m}$ & $4.37 \pm 1.26 \mathrm{kl}$ \\
\hline Pentadecane & $83.05 \pm 0.83$ & $87.75 \pm 0.25$ & $86.92 \pm 1.01$ & $88.00 \pm 0.00$ & $-o p$ & $-\mathrm{O}$ \\
\hline 2-Tridecanol ${ }^{4}$ & $83.05 \pm 0.83$ & $87.75 \pm 0.25$ & $67.47 \pm 1.73$ & $84.33 \pm 0.38$ & $19.97 \pm 2.22 j$ & $4.13 \pm 0.46 \mathrm{klm}$ \\
\hline Butylated Hydroxytoluene & $83.05 \pm 0.83$ & $87.75 \pm 0.25$ & $76.13 \pm 0.81$ & $85.40 \pm 0.26$ & $8.86 \pm 1.041$ & $2.84 \pm 0.31 \mathrm{lmn}$ \\
\hline 2-Tetradecanone ${ }^{3}$ & $83.05 \pm 0.83$ & $87.75 \pm 0.25$ & $84.42 \pm 0.88$ & $88.00 \pm 0.00$ & - mno & $-\mathrm{O}$ \\
\hline 2-Tetradecanol ${ }^{4}$ & $83.05 \pm 0.83$ & $87.75 \pm 0.25$ & $71.77 \pm 1.67$ & $85.95 \pm 0.51$ & $14.46 \pm 2.13 \mathrm{k}$ & $2.18 \pm 0.61 \mathrm{lmn}$ \\
\hline Hexadecane & $83.05 \pm 0.83$ & $87.75 \pm 0.25$ & $86.37 \pm 0.64$ & $88.00 \pm 0.00$ & - nop & $-\mathrm{O}$ \\
\hline Tetradecanal & $83.05 \pm 0.83$ & $87.75 \pm 0.25$ & $75.28 \pm 1.34$ & $82.50 \pm 1.32$ & $9.95 \pm 1.711$ & $6.34 \pm 1.60 \mathrm{k}$ \\
\hline 2,2',5,5'-Tetramethyl-1,1'-biphenyl & $83.05 \pm 0.83$ & $87.75 \pm 0.25$ & $83.30 \pm 0.72$ & $88.00 \pm 0.00$ & $-\mathrm{m}$ & $-\mathrm{O}$ \\
\hline Heptadecane & $83.05 \pm 0.83$ & $87.75 \pm 0.25$ & $84.72 \pm 0.80$ & $86.68 \pm 0.70$ & - mno & $1.29 \pm 0.85$ no \\
\hline 2-Hexadecanone ${ }^{3}$ & $83.05 \pm 0.83$ & $87.75 \pm 0.25$ & $84.58 \pm 1.01$ & $86.18 \pm 0.28$ & - mno & $1.89 \pm 0.34 \mathrm{mno}$ \\
\hline Octadecane & $83.05 \pm 0.83$ & $87.75 \pm 0.25$ & $84.33 \pm 1.26$ & $85.88 \pm 0.81$ & $-\mathrm{mn}$ & $2.26 \pm 0.98 \mathrm{lmn}$ \\
\hline
\end{tabular}

1 " $-"$ indicates no antifungal activity. ${ }^{2}$ Data are the mean \pm standard deviation $(n=3)$. In the same column, data with different lowercase letters are significantly different according to Duncan's multiple range test $(p<0.05) .{ }^{3}$ Compound was dissolved with acetone. ${ }^{4}$ Compound was dissolved with methanol 


\subsection{Identification of Antagonistic Bacterium CT32}

The cells of strain CT32 are Gram-positive rods, $(0.5-0.7) \times(1.5-4.2) \mu \mathrm{m}$, occurring singly and occasionally in pairs. Endospores are ellipsoidal and lie in subterminal positions in non-swollen sporangia (Figure 4). The 16S rRNA gene sequence of strain CT32 (GenBank accession number MT509863) comprised 1381 nucleotides. A BLAST search of GenBank revealed that the unidentified bacterium was a member of the genus Bacillus. A neighbor-joining tree depicting the phylogenetic affinity of the unidentified strain CT32 is shown in Figure 5. Tree analysis showed that strain CT32 was most closely related to $B$. velezensis $\mathrm{CBMB205}^{\mathrm{T}}$. Pairwise comparison revealed approximately 99\% sequence similarity between bacterial strain $\mathrm{CT} 32$ and the $\mathrm{CBMB} 205^{\mathrm{T}}$ and $\mathrm{FZB} 42^{\mathrm{T}}$ type strains of B. velezensis. Thus, strain CT32 was identified as B. velezensis.

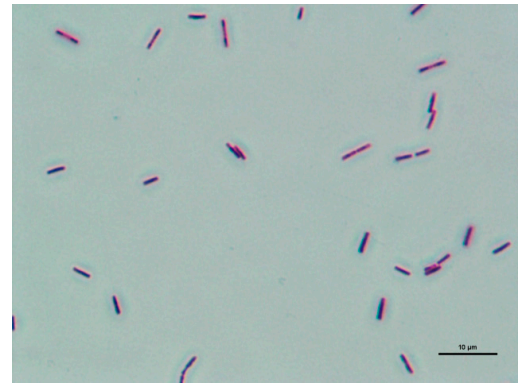

(a)

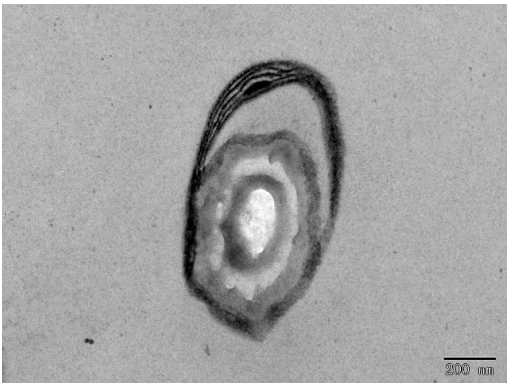

(b)

Figure 4. (a) Light micrograph of strain CT32 cell morphology; (b) transmission electron microscopy image of strain CT32 endospore.

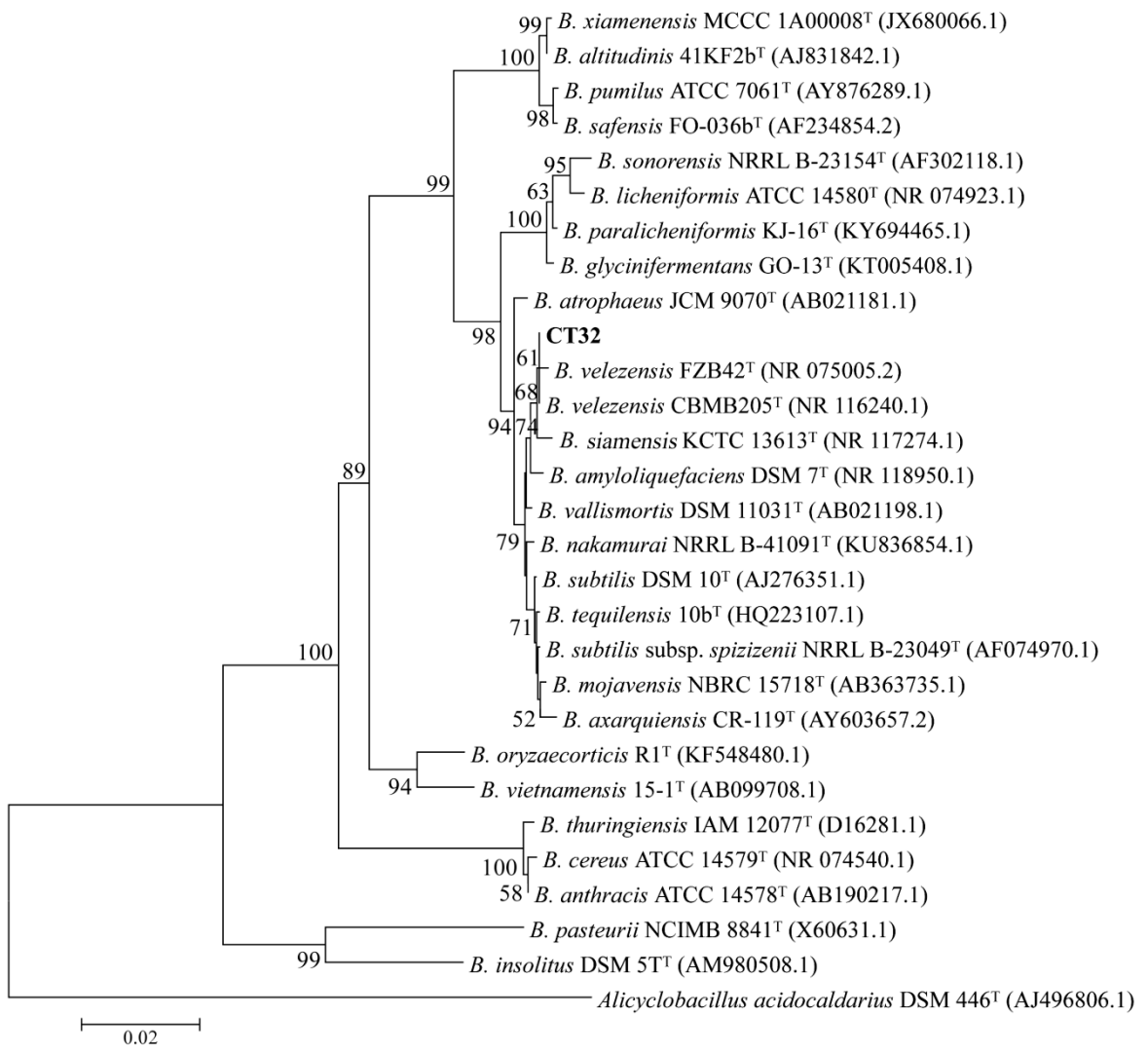

Figure 5. Neighbor-joining (NJ) tree based on $16 \mathrm{~S}$ rRNA gene sequences, highlighting the phylogenetic relationship of strain CT32 to other strain types of the genus Bacillus. Bootstrap values (1000 replications) greater than $50 \%$ are given at branch points. Scale bar $=0.02$ substitutions per nucleotide position. 


\section{Discussion}

Vascular wilts are devastating plant diseases that cause major economic losses in strawberry production globally. The present work aims to address this issue by isolating potential bacterial antagonists that can be integrated into disease management strategies. In this study, 73 strains of bacteria were isolated from maize straw compost tea and screened for their ability to produce VOCs with antifungal activity against $V$. dahliae and FOF. One of the most effective isolates, designated as CT32, was identified as B. velezensis. Members of the species B. velezensis are well known for their ability to promote plant growth and to synthesize of a diverse array of secondary metabolites, such as bacillomycin D, plantazolicin and amylocyclicin, that can inhibit the growth of plant pathogens [25-28]. Our results provide evidence that VOC production can play an essential role in the biocontrol activity of $B$. velezensis CT32 against vascular wilt pathogens.

A broad-spectrum antifungal effect was exhibited by VOCs emitted by strain CT32, even though the inhibition rate was low for some pathogenic fungi. The experimental data revealed that the extent of inhibition varied greatly depending on the fungal species. This is consistent with the results obtained by Che et al. [29], who reported that the volatiles from Lysinibacillus sp. FJAT-4748 did not affect the growth of all pathogenic fungi to the same extent. The observed differences in fungal susceptibilities to bacterial VOCs may be explained by differences in the action site or in the ability of fungal pathogens to detoxify the volatiles [30]. In addition, considering that different isolates of each pathogen type vary in terms of their physiological properties and pathogenicity, the inhibitory effect on one pathogen isolate observed in our study may not represent the responses of all isolates of the species to bacterial volatiles. Notably, the VOCs produced by strain CT32 were particularly active in inhibiting the mycelial growth of $V$. dahliae and F. oxysporum. Similarly, previous studies have reported the in vitro growth inhibition of tomato vascular wilt pathogens by VOCs released from Bacillus spp.; however, they did not identify the bioactive compounds responsible for the inhibition [31,32].

To identify the volatile compounds composing the natural emissions of strain CT32, HS-SPME-GC-MS was employed. In comparison with other sampling techniques, HS-SPME allows the volatile metabolites in the headspace of the bacterial cultures to be preconcentrated prior to analysis by GC-MS [33]. In fact, HS-SPME-GC-MS has been used for profiling VOCs from various microbial samples without contaminating the culture or causing damage to living cells [34-36]. The results of this study show that the volatile blend produced by strain CT32 comprised 30 individual compounds. To the best of our knowledge, six of the 30 identified volatiles have not previously been reported to be produced by bacteria or fungi: (Z)-5-undecene, decyl formate, 2,4-dimethyl-6-tert-butylphenol, dodecanenitrile, 2-methylpentadecane and 2,2',5,5'-tetramethyl-1,1'-biphenyl. The predominant classes of compounds detected in the headspace of strain CT32 were alkanes, ketones, alcohols, and aldehydes. However, Dhouib et al. [31] reported that terpenes, alcohols, and alkanes were the major classes of compounds released from the endophytic B. velezensis strain $C 2$. This discrepancy may be explained by the different methods applied to collect and detect VOCs. It needs to be recognized that bacterial VOC profiles are greatly influenced by the sample preparation method as well as the extraction and chromatographic procedures, such as the choice of culture media, duration of incubation, choice of capillary column and selection of SPME fibres, all of which can lead to inconsistent results and hinder the comparison between different studies.

To investigate the precise contribution of 26 commercially available compounds identified in the headspace of strain CT32 to the previously observed volatile-mediated inhibition of mycelial growth, we assessed their antifungal activity against $V$. dahliae and FOF. The majority of the tested compounds showed low to moderate fungistatic effects, while benzothiazole exhibited $100 \%$ inhibition against the two tested pathogens. Benzothiazole is widely found in the volatiles produced by Paenibacillus polymyxa, Bacillus spp., Ensifer adhaerens, Stenotrophomonas maltophilia, Sporosarcina ginsengisoli and Arthrobacter nitroguajacolicus [37,38]. This sulphur-containing heterocyclic compound has been shown to display a wide range of pharmacological and biological properties, such as antifungal, anticancer, antidiabetic and antimicrobial activities [39]. A previous study based on 
transcriptomic and proteomic analyses has suggested that benzothiazole has antimicrobial activity against Phytophthora capsici by suppressing detoxification and stress responses as well as by inducing apoptosis [40]. In the present study, 2,4-dimethyl-6-tert-butylphenol showed excellent growth inhibition towards all of the fungi tested in vitro (reaching $>90 \%$ inhibition), and thus this phenolic antioxidant can be considered a potential inhibitor of phytopathogenic fungi. Dodecanenitrile is an important fragrance ingredient widely used in consumer products such as detergents and cosmetics, but its effect on fungal growth has so far not been reported. In the present study, this nitrogen-containing compound greatly hindered the mycelial growth of $V$. dahliae and FOF.

According to the mVOC 2.0 database, almost $70 \%$ of the recorded VOCs produced by Bacillus spp. are fatty acid derivatives, for example, alkenes, alcohols, ketones, and aldehydes, which make them the most important group of volatile metabolites [41]. Alcohols have long been known to display broad antimicrobial activity and are utilized as preservatives or disinfectants [42]. All five alcohols assayed in this study showed antifungal activity against both pathogens. In addition, we found that the antifungal activity of alcohols was negatively correlated with the number of carbon atoms in the alcohols, and thus, 2-undecanol showed the highest level of inhibition. As proposed by Yuan et al. [43], the antifungal activities of ketones towards F. oxysporum f. sp. cubense decreased in the following order: 2-undecanone $>2$-dodecanone $>2$-tridecanone. In this work, when individual compounds were tested on $V$. dahliae and FOF, this order was also observed. In addition, 3-undecanone was proven to be effective against the two target pathogens. The antimicrobial properties of aldehydes have been demonstrated in previous studies, for example, the in vitro inhibition of Sclerotinia sclerotiorum by decanal and nonanal [44] and the in vitro inhibition of $P$. infestans by undecanal and tridecanal [45]. Similarly, decanal and undecanal showed high antifungal activity against the mycelial growth of $V$. dahliae and FOF, but they were produced in low amounts. In contrast, dodecanal was the most abundant compound in the headspace of strain CT32, but it had a weak effect on the mycelial growth of the two target pathogens. The results presented here indicate that the inhibition of $V$. dahliae and FOF observed with the natural emissions of strain CT32 is probably not caused by one or a few of these compounds but is most likely the result of synergistic or additive actions of various components of the complex mixture.

However, our study was performed in vitro, which differs from that under natural conditions as most of the volatiles evaporate easily under greenhouse and field conditions. Nevertheless, field applications of bacterial VOCs have been reported recently, and some showed promising results. For example, drench application of 2-butanone emitted from Bacillus spp. on cucumber seedlings consistently triggered a higher resistance against bacterial pathogens, decreased the Myzus persicae population, as well as increased the number of ladybird beetles, even under open-field conditions [46]. Further studies are needed to develop appropriate application techniques and formulations for the effective usage of bacterial VOCs.

\section{Conclusions}

The data obtained confirmed the antifungal activity of B. velezensis CT32 towards eight plant pathogens and indicated the pivotal role of VOC production in antagonist-pathogen interactions. GC-MS analysis of the bacterial volatile profile suggested the contribution of ketones, alcohols, aldehydes, phenols, nitrogen compound and thiazole to the antifungal property of strain CT32 emissions, which was verified by in vitro assays where individual chemical compounds were tested against the mycelial growth of $V$. dahliae and FOF. Among these compounds, benzothiazole and 2,4-dimethyl-6-tert-butylphenol showed the strongest antifungal activity. These findings will hopefully provide lead compounds for the development of new antifungal agents. Although further studies are required to evaluate the efficacy of the volatile-producing strain CT32 for the protection of strawberry plants, it shows potential to be used as a biofumigant for the control of vascular wilt diseases.

Supplementary Materials: The following are available online at http://www.mdpi.com/2227-9717/8/12/1674/s1, Table S1: Volatile compounds identified in the headspace of strain CT32 by HS-SPME-GC-MS. 
Author Contributions: Conceptualization, X.L. and S.Z.; methodology, X.W.; validation, B.W., Q.W. and M.L.; formal analysis, X.L.; investigation, M.L.; resources, S.Z.; data curation, Q.W.; writing-original draft preparation, X.L.; writing-review and editing, S.Z.; supervision, X.S.; project administration, B.W.; funding acquisition, X.L. All authors have read and agreed to the published version of the manuscript.

Funding: This research was funded by the Key Research and Development Program of Shanxi Province, grant number 201703D211022; the Postdoctoral Foundation of Shanxi Academy of Agricultural Sciences, grant number YCX2018D2BH1 and the Agricultural Science and Technology Innovation Programs of Shanxi Academy of Agricultural Sciences, grant number YGC2019TD07, YCX2020YQ24.

Acknowledgments: The authors would like to acknowledge everyone who has provided helpful guidance.

Conflicts of Interest: The authors declare no conflict of interest.

\section{References}

1. Eljounaidi, K.; Lee, S.K.; Bae, H. Bacterial endophytes as potential biocontrol agents of vascular wilt diseases-Review and future prospects. Biol. Control 2016, 103, 62-68. [CrossRef]

2. Yadeta, K.A.; Thomma, B.P.H.J. The xylem as battleground for plant hosts and vascular wilt pathogens. Front. Plant Sci. 2013, 4, 97. [CrossRef]

3. Bell, C. Fumigation in the 21st century. Crop. Prot. 2000, 19, 563-569. [CrossRef]

4. Roux-Michollet, D.; Czarnes, S.; Adam, B.; Berry, D.; Commeaux, C.; Guillaumaud, N.; Le Roux, X.; Clays-Josserand, A. Effects of steam disinfestation on community structure, abundance and activity of heterotrophic, denitrifying and nitrifying bacteria in an organic farming soil. Soil Biol. Biochem. 2008, 40, 1836-1845. [CrossRef]

5. Emmert, E.A.B.; Handelsman, J. Biocontrol of plant disease: A (Gram-) positive perspective. FEMS Microbiol. Lett. 1999, 171, 1-9. [CrossRef]

6. Ongena, M.; Jacques, P. Bacillus lipopeptides: Versatile weapons for plant disease biocontrol. Trends Microbiol. 2008, 16, 115-125. [CrossRef]

7. Fira, D.; DimkiC, I.; Beric, T.; Lozo, J.; Stankovic, S. Biological control of plant pathogens by Bacillus species. J. Biotechnol. 2018, 285, 44-55. [CrossRef]

8. Kai, M.; Haustein, M.; Molina, F.; Petri, A.; Scholz, B.; Piechulla, B. Bacterial volatiles and their action potential. Appl. Microbiol. Biotechnol. 2009, 81, 1001-1012. [CrossRef]

9. Effmert, U.; Kalderás, J.; Warnke, R.; Piechulla, B. Volatile Mediated Interactions Between Bacteria and Fungi in the Soil. J. Chem. Ecol. 2012, 38, 665-703. [CrossRef]

10. Farag, M.A.; Zhang, H.; Ryu, C.-M. Dynamic Chemical Communication between Plants and Bacteria through Airborne Signals: Induced Resistance by Bacterial Volatiles. J. Chem. Ecol. 2013, 39, 1007-1018. [CrossRef]

11. Fincheira, P.; Quiroz, A. Microbial volatiles as plant growth inducers. Microbiol. Res. 2018, 208, 63-75. [CrossRef] [PubMed]

12. Kanchiswamy, C.N.; Emalnoy, M.; Maffei, M.E. Chemical diversity of microbial volatiles and their potential for plant growth and productivity. Front. Plant Sci. 2015, 6, 151. [CrossRef] [PubMed]

13. Lee, B.; Farag, M.A.; Park, H.B.; Kloepper, J.W.; Lee, S.H.; Ryu, C. Induced Resistance by a Long-Chain Bacterial Volatile: Elicitation of Plant Systemic Defense by a C13 Volatile Produced by Paenibacillus polymyxa. PLoS ONE 2012, 7, e48744. [CrossRef]

14. Ryu, C.-M.; Farag, M.A.; Hu, C.-H.; Reddy, M.S.; Kloepper, J.W.; Pare, P.W. Bacterial Volatiles Induce Systemic Resistance in Arabidopsis. Plant Physiol. 2004, 134, 1017-1026. [CrossRef] [PubMed]

15. Ryu, C.-M.; Farag, M.A.; Hu, C.-H.; Reddy, M.S.; Wei, H.-X.; Paré, P.W.; Kloepper, J.W. Bacterial volatiles promote growth in Arabidopsis. Proc. Natl. Acad. Sci. USA 2003, 100, 4927-4932. [CrossRef] [PubMed]

16. Mercier, J.; Lego, S.F.; Smilanick, J.L. In-package use of Muscodor albus volatile-generating sachets and modified atmosphere liners for decay control in organic table grapes under commercial conditions. Fruits 2010, 65, 31-38. [CrossRef]

17. Mercier, J.; Jiménez, J.I. Potential of the volatile-producing fungus Muscodor albus for control of building molds. Can. J. Microbiol. 2007, 53, 404-410. [CrossRef]

18. Riga, E.; Lacey, L.A.; Guerra, N. Muscodor albus, a potential biocontrol agent against plant-parasitic nematodes of economically important vegetable crops in Washington State, USA. Biol. Control 2008, 45, 380-385. [CrossRef] 
19. Wang, C.; Wang, Z.; Qiao, X.; Li, Z.; Li, F.; Chen, M.; Wang, Y.; Huang, Y.; Cui, H. Antifungal activity of volatile organic compounds fromStreptomyces alboflavusTD-1. FEMS Microbiol. Lett. 2013, 341, 45-51. [CrossRef]

20. Zhou, J.; Zhao, X.; Dai, C. Antagonistic mechanisms of endophytic Pseudomonas fluorescens against Athelia rolfsii. J. Appl. Microbiol. 2014, 117, 1144-1158. [CrossRef]

21. Zhang, X.; Gao, Z.; Zhang, X.; Bai, W.; Zhang, L.; Pei, H.; Zhang, Y. Control effects of Bacillus siamensis G-3 volatile compounds on raspberry postharvest diseases caused by Botrytis cinerea and Rhizopus stolonifer. Biol. Control 2020, 141, 104135. [CrossRef]

22. Li, X.; Wang, X.; Shi, X.; Wang, Q.; Li, X.; Zhang, S. Compost tea-mediated induction of resistance in biocontrol of strawberry Verticillium wilt. J. Plant Dis. Prot. 2019, 127, 257-268. [CrossRef]

23. Gao, Z.; Zhang, B.; Liu, H.; Han, J.; Zhang, Y. Identification of endophytic Bacillus velezensis ZSY-1 strain and antifungal activity of its volatile compounds against Alternaria solani and Botrytis cinerea. Biol. Control 2017, 105, 27-39. [CrossRef]

24. Bianchi, F.; Careri, M.; Mangia, A.; Musci, M. Retention indices in the analysis of food aroma volatile compounds in temperature-programmed gas chromatography: Database creation and evaluation of precision and robustness. J. Sep. Sci. 2007, 30, 563-572. [CrossRef] [PubMed]

25. Fan, B.; Wang, C.; Song, X.; Ding, X.; Wu, L.; Wu, H.; Gao, X.; Borriss, R. Bacillus velezensis FZB42 in 2018: The Gram-Positive Model Strain for Plant Growth Promotion and Biocontrol. Front. Microbiol. 2018, 9, 2491. [CrossRef] [PubMed]

26. Meng, Q.; Jiang, H.; Hao, J. Effects of Bacillus velezensis strain BAC03 in promoting plant growth. Biol. Control 2016, 98, 18-26. [CrossRef]

27. Scholz, R.; Molohon, K.J.; Nachtigall, J.; Vater, J.; Markley, A.L.; Süssmuth, R.D.; Mitchell, D.A.; Borriss, R. Plantazolicin, a Novel Microcin B17/Streptolysin S-Like Natural Product from Bacillus amyloliquefaciens FZB42. J. Bacteriol. 2010, 193, 215-224. [CrossRef]

28. Scholz, R.; Vater, J.; Budiharjo, A.; Wang, Z.; He, Y.; Dietel, K.; Schwecke, T.; Herfort, S.; Lasch, P.; Borriss, R. Amylocyclicin, a Novel Circular Bacteriocin Produced by Bacillus amyloliquefaciens FZB42. J. Bacteriol. 2014, 196, 1842-1852. [CrossRef]

29. Che, J.; Liu, B.; Liu, G.; Chen, Q.; Lan, J. Volatile organic compounds produced by Lysinibacillus sp. FJAT-4748 possess antifungal activity against Colletotrichum acutatum. Biocontrol Sci. Technol. 2017, 27, 1349-1362. [CrossRef]

30. Chaves-López, C.; Serio, A.; Gianotti, A.; Sacchetti, G.; Ndagijimana, M.; Ciccarone, C.; Stellarini, A.; Corsetti, A.; Paparella, A. Diversity of food-borne Bacillus volatile compounds and influence on fungal growth. J. Appl. Microbiol. 2015, 119, 487-499. [CrossRef]

31. Dhouib, H.; Zouari, I.; Ben Abdallah, D.; Belbahri, L.; Taktak, W.; Triki, M.A.; Tounsi, S. Potential of a novel endophytic Bacillus velezensis in tomato growth promotion and protection against Verticillium wilt disease. Biol. Control 2019, 139, 104092. [CrossRef]

32. Jangir, M.; Pathak, R.; Sharma, S.; Sharma, S. Biocontrol mechanisms of Bacillus sp., isolated from tomato rhizosphere, against Fusarium oxysporum f. sp. lycopersici. Biol. Control 2018, 123, 60-70. [CrossRef]

33. A Farag, M.; Song, G.C.; Park, Y.; Audrain, B.; Lee, S.; Ghigo, J.-M.; Kloepper, J.W.; Ryu, C.-M. Biological and chemical strategies for exploring inter- and intra-kingdom communication mediated via bacterial volatile signals. Nat. Protoc. 2017, 12, 1359-1377. [CrossRef] [PubMed]

34. Castillo, M.; da Silva, E.; Câmara, J.S.; Khadem, M. Molecular identification and VOMs characterization of Saccharomyces cerevisiae strains isolated from madeira region winery environments. Processes 2020, 8, 1058. [CrossRef]

35. Ghader, M.; Shokoufi, N.; Es-Haghi, A.; Kargosha, K. Headspace solid-phase microextraction (HS-SPME) combined with GC-MS as a process analytical technology (PAT) tool for monitoring the cultivation of C. tetani. J. Chromatogr. B 2018, 1083, 222-232. [CrossRef] [PubMed]

36. Romoli, R.; Papaleo, M.C.; De Pascale, D.; Tutino, M.L.; Michaud, L.; Logiudice, A.; Fani, R.; Bartolucci, G. Characterization of the volatile profile of Antarctic bacteria by using solid-phase microextraction-gas chromatography-mass spectrometry. J. Mass Spectrom. 2011, 46, 1051-1059. [CrossRef]

37. Zhao, L.-J.; Yang, X.-N.; Li, X.-Y.; Mu, W.; Liu, F. Antifungal, Insecticidal and Herbicidal Properties of Volatile Components from Paenibacillus polymyxa Strain BMP-11. Agric. Sci. China 2011, 10, 728-736. [CrossRef] 
38. Zou, C.-S.; Mo, M.-H.; Gu, Y.-Q.; Zhou, J.; Zhang, K.-Q. Possible contributions of volatile-producing bacteria to soil fungistasis. Soil Biol. Biochem. 2007, 39, 2371-2379. [CrossRef]

39. Agarwal, S.; Gandhi, D.; Kalal, P. Benzothiazole: A Versatile and Multitargeted Pharmacophore in the Field of Medicinal Chemistry. Lett. Org. Chem. 2017, 14, 729-742. [CrossRef]

40. Mei, X.; Liu, Y.; Huang, H.; Du, F.; Huang, L.; Wu, J.; Li, Y.; Zhu, S.; Yang, M. Benzothiazole inhibits the growth of Phytophthora capsici through inducing apoptosis and suppressing stress responses and metabolic detoxification. Pestic. Biochem. Physiol. 2019, 154, 7-16. [CrossRef]

41. Caulier, S.; Nannan, C.; Gillis, A.; Licciardi, F.; Bragard, C.; Mahillon, J. Overview of the Antimicrobial Compounds Produced by Members of the Bacillus subtilis Group. Front. Microbiol. 2019, 10, 302. [CrossRef] [PubMed]

42. Ingram, L.O.; Buttke, T.M. Effects of Alcohols on Micro-Organisms. Adv. Microb. Physiol. 1985, 25, $253-300$. [CrossRef]

43. Yuan, J.; Raza, W.; Shen, Q.; Huang, Q. Antifungal Activity of Bacillus amyloliquefaciens NJN-6 Volatile Compounds against Fusarium oxysporum f. sp. cubense. Appl. Environ. Microbiol. 2012, 78, 5942-5944. [CrossRef] [PubMed]

44. Fernando, W.G.D.; Ramarathnam, R.; Krishnamoorthy, A.S.; Savchuk, S.C. Identification and use of potential bacterial organic antifungal volatiles in biocontrol. Soil Biol. Biochem. 2005, 37, 955-964. [CrossRef]

45. De Vrieze, M.; Pandey, P.; Bucheli, T.D.; Varadarajan, A.R.; Ahrens, C.H.; Weisskopf, L.; Bailly, A. Volatile Organic Compounds from Native Potato-associated Pseudomonas as Potential Anti-oomycete Agents. Front. Microbiol. 2015, 6, 1295. [CrossRef]

46. Song, K.C.; Ryu, C.-M. Two Volatile Organic Compounds Trigger Plant Self-Defense against a Bacterial Pathogen and a Sucking Insect in Cucumber under Open Field Conditions. Int. J. Mol. Sci. 2013, 14, 9803-9819. [CrossRef] [PubMed]

Publisher's Note: MDPI stays neutral with regard to jurisdictional claims in published maps and institutional affiliations.

(C) 2020 by the authors. Licensee MDPI, Basel, Switzerland. This article is an open access article distributed under the terms and conditions of the Creative Commons Attribution (CC BY) license (http://creativecommons.org/licenses/by/4.0/). 